\title{
Risk of hepatitis B infection among medical and paramedical workers in a general hospital in Zimbabwe
}

\author{
J C EMMANUEL, ${ }^{*}$ M T BASSETT, H J SMITH*
}

From the *Blood Transfusion Service, Harare, Zimbabwe, and the Department of Community Medicine, University of Zimbabwe

SUMMARY To evaluate the addition of hepatitis vaccine to health schemes for hospital workers in Zimbabwe we undertook a cross sectional study of viral markers in 226 hospital workers and compared the results with 97 volunteer blood donor controls. One hundred and thirty one (58\%) hospital workers had hepatitis markers compared with $45(46 \%)$ of the donor group. Racial group was the strongest risk factor. Blacks were $70 \%$ more likely to have markers than whites. This racial difference was not explained by job status or patient contact.

Our data suggest that work in a district general hospital does not constitute a clinically important hazard for hepatitis B infection. Because of the high cost of the vaccine, additional studies to assess the risk of hospital work in other settings in Zimbabwe are required before health policy regarding routine hepatitis $B$ vaccination is determined.

Hospital workers in contact with patients or blood products are at an increased risk of becoming infected with hepatitis B virus (HBV). ' Some epidemiological studies in the West have shown this risk to be three to five fold higher than that of volunteer blood donors, ${ }^{1-4}$ other studies have shown no significant difference in the prevalence of HBV markers between the two groups. ${ }^{.12}$

Protection against this occupational hazard became possible in 1981 when the hepatitis vaccine was licensed for commercial production and sale. As many as $10 \%$ of $\mathrm{HBV}$ infected patients may go on to become chronic carriers of the virus, with a risk of chronic liver disease, cirrhosis, and more rarely, hepatocellular carcinoma. Vaccination of high risk populations is therefore prudent and should be included in health schemes for workers if it can be shown that their jobs place them at increased risk of infection.

Most Western countries currently recommend the vaccine for hospital workers, ${ }^{5}$ as does the World Health Organisation. ${ }^{6}$ Unfortunately, the vaccine currently used is derived from plasma and is expensive. The current cost in Zimbabwe is $Z \$ 100$ for each vaccine.

Recent studies have shown that the prevalence of

Accepted for publication 5 October 1987 hepatitis B surface antigen (HBsAg) in Zimbabwe is $14 \%$ compared with between $0.25-0.5 \%$ in the United States and most of Europe. ${ }^{78}$ Because of this high prevalence it is necessary to define the risk of hospital work in Zimbabwe before embarking on costly vaccination programmes.

At present, the risk of $\mathrm{HBV}$ infection among hospital workers in Zimbabwe is unknown. We undertook a cross sectional study of a group of hospital workers and volunteer blood donors to determine whether hospital workers were at greater risk, and, if so, whether subgroups of hospital workers at particularly high risk could be identified.

\section{Material and methods}

The population studied were employees of Parirenyatwa Hospital, a government referral hospital in Harare. Employee volunteers $(n=226)$ were drawn from two inpatient wards $(\mathrm{n}=58)$, the outpatient department $(n=25)$, the mortuary $(n=7)$, administration $(n=5)$, pharmacy $(n=19)$, and kitchen staff $(n=112)$. The final sample contained 200 blacks and 26 whites. Ninety five employees had regular patient contact.

The control group comprised a random sample of volunteer blood donors $(\mathrm{n}=97)$, who donated blood either under the auspices of the Blood Transfusion 
Table 1 Prevalence of hepatitis B markers among hospital workers and volunteer blood donors

\begin{tabular}{|c|c|c|c|c|c|}
\hline \multirow[b]{2}{*}{ Site } & \multirow[b]{2}{*}{ No } & \multicolumn{4}{|l|}{ One or more } \\
\hline & & $\begin{array}{l}\text { HBV markers } \\
\text { No }(\%)\end{array}$ & $H B s A g$ & $A n t i-H B s$ & $A n t i-H B c$ \\
\hline Hospital workers & 226 & $131(58)$ & & & \\
\hline $\begin{array}{l}\text { Departments: } \\
\text { Administration } \\
\text { Mortuary } \\
\text { Outpatients } \\
\text { Inpatient wards } \\
\text { Pharmacy } \\
\text { Kitchen }\end{array}$ & $\begin{array}{r}5 \\
7 \\
25 \\
58 \\
19 \\
112\end{array}$ & $\begin{array}{r}2(40) \\
6(86) \\
12(48) \\
35(60) \\
12(63) \\
64(57)\end{array}$ & $\begin{array}{l}1 \\
1 \\
1 \\
2 \\
1 \\
9\end{array}$ & $\begin{array}{r}1 \\
5 \\
11 \\
32 \\
10 \\
53\end{array}$ & $\begin{array}{r}2 \\
6 \\
6 \\
27 \\
12 \\
57\end{array}$ \\
\hline Blood donors & 97 & $45(46)$ & & & \\
\hline
\end{tabular}

Service or the Red Cross. We excluded donors who were hospital workers. The final sample contained 56 blacks and 41 whites.

The presence of HBsAg, antibody to hepatitis B surface antigen (anti-HBs), and antibody to hepatitis B core antigen (anti-HBc) were tested using kits manufactured by Abbott Laboratories. The AUSRIA 11-125 radioimmunoassay was used for the detection of HBsAg. AUSAB enzyme immunoassay was used for the detection of antibody to HBsAg and CORZYME enzyme immunoassay was used for the detectio of antibody to $\mathrm{HBcAg}$.

We used the $\chi^{2}$ test for proportions, with the MantelHaenzel adjustment where appropriate. ${ }^{8}$

\section{Results}

The distribution of HBV markers among hospital workers and volunteer blood donors is shown in table 1. Fifty eight per cent of hospital staff had one or more markers for $\mathrm{HBV}$ infection compared with $46 \%$ of the donor population ( $p=0.028$, one sided test). This difference shows a significantly increased risk of about $20 \%$ among hospital workers.

The proportion of workers with HBsAg (which correlates with infectivity) did not vary among subgroups. Mortuary workers had a higher rate of HBV markers than outpatients, but no subgroup differed significantly in overall prevalence from hospital employees.

In contrast, there were striking differences in the prevalence of $\mathrm{HBV}$ markers and $\mathrm{HBsAg}$ between blacks and whites. In the entire group (donors and hospital workers) blacks were $70 \%$ more likely to have one or more HBV markers than whites ( $p<0.001$ ). There were significant differences in the racial composition of the hospital and donor groups: $89 \%$ of hospital workers were black compared with $58 \%$ of the donor group (table 2). When risk for HBV markers among hospital workers was adjusted for the differences in racial composition of both groups, the difference in risk previously noted for hospital workers became insignificant $\left(\chi^{2} \mathrm{M}-\mathrm{H}=0.72, \mathrm{p}=0.235\right)$.

To test the hypothesis that differences in job status or patient contact accounted for the observed racial differences, we categorised the hospital staff into "high status" (doctors, nurses, administrative staff, pharmacy staff) or "low status" (mortuary staff, kitchen staff, orderlies), and "patient contact" or "no patient contact" groups (table 3). Among black hospital workers there was an excess risk of HBV markers of about $60 \%$, regardless of job status or patient contact compared with hospital workers. Comparison of blacks and whites after adjustment for job status showed persistence of a significant difference in HBV markers by race $\left(\chi^{2} \mathbf{M}-H=5.86, p<0.01\right)$. Similarly, adjustment for patient contact status did not eliminate the risk attributable to race $\left(\chi^{2} \mathrm{M}-\mathrm{H}=9.08, \mathrm{p}<0.05\right)$.

\section{Discussion}

The prevalence of HBV infection in Zimbabwe, and all of sub-Saharan Africa, is high. Researchers in the West have shown that hospital workers face an

Table 2 Prevalence of hepatitis $B$ markers by race and site

\begin{tabular}{|c|c|c|c|c|}
\hline Site & $N o$ & $\begin{array}{l}\text { Percentage of } \\
\text { total group }\end{array}$ & $\begin{array}{l}\text { No with } \\
\text { HBV markers }\end{array}$ & $\begin{array}{l}\text { Percentage of racial group } \\
\text { with } H B V \text { markers }\end{array}$ \\
\hline $\begin{array}{c}\text { Hospital w } \\
\text { Blacks } \\
\text { Whites } \\
\text { Total }\end{array}$ & $\begin{array}{r}200 \\
26 \\
226\end{array}$ & $\begin{array}{l}88 \cdot 5 \\
11 \cdot 5\end{array}$ & $\begin{array}{r}123 \\
8 \\
131\end{array}$ & $\begin{array}{l}61 \cdot 5 \\
30 \cdot 8 \\
58 \cdot 0\end{array}$ \\
\hline $\begin{array}{c}\text { Donors } \\
\text { Blacks } \\
\text { Whites } \\
\text { Total }\end{array}$ & $\begin{array}{l}56 \\
41 \\
97\end{array}$ & $\begin{array}{l}57 \cdot 7 \\
42 \cdot 3\end{array}$ & $\begin{array}{l}30 \\
15 \\
45\end{array}$ & $\begin{array}{l}53.6 \\
36.6 \\
46.4\end{array}$ \\
\hline
\end{tabular}


Table 3 Prevalence of $H B V$ markers by job occupation and patient contact

\begin{tabular}{|c|c|c|c|}
\hline & No in group & $\begin{array}{l}\text { No with one } \\
\text { or more } H B V \\
\text { markers }\end{array}$ & $\begin{array}{l}\text { Percentage of } \\
\text { group with } \\
\text { HBV markers }\end{array}$ \\
\hline \multicolumn{4}{|c|}{ High status: } \\
\hline Blacks & 46 & 29 & $63 \cdot 0$ \\
\hline Whites & 16 & 4 & $25 \cdot 0$ \\
\hline Total & 62 & & \\
\hline \multicolumn{4}{|c|}{ Low status: } \\
\hline Blacks & 154 & 94 & $61 \cdot 0$ \\
\hline Whites & 10 & 5 & $50 \cdot 0$ \\
\hline Total & 164 & & \\
\hline \multicolumn{4}{|c|}{ Patient contact: } \\
\hline Blacks & 78 & 51 & $65 \cdot 4$ \\
\hline Whites & 17 & 4 & $23 \cdot 5$ \\
\hline Total & 95 & & \\
\hline \multicolumn{4}{|c|}{ No patient contact: } \\
\hline Blacks & 122 & 72 & $59 \cdot 0$ \\
\hline Whites & 9 & 4 & $44 \cdot 4$ \\
\hline Total & 131 & & \\
\hline
\end{tabular}

increased risk of exposure to hepatitis $B$ virus. ${ }^{1-4}$ Hepatitis B vaccine is recommended for preventing $\mathrm{HBV}$ infection and its sequelae. Because of the higher prevalence of $\mathrm{HBsAg}$ in the Zimbabwean population, it is reasonable to ask whether hospital workers face an even higher risk of infection than reported in low prevalence countries, and should therefore be offered vaccination despite its considerable cost.

Our data show that hospital workers in this setting are not at significantly increased risk for $\mathrm{HBV}$ infection, irrespective of patient contact, and irrespective of their job status. The workers in our study had a prevalence of HBV markers no different from that of a randomly selected group of volunteer blood donors, once race was taken into account. The major risk factor for HBV markers was racial group, not site of work. Blacks, on average, had a $70 \%$ higher risk of having one or more HBV markers than whites. These findings agree with those of Hoffman-Panetta et al and Borek et al, who showed that employees of blood centres were not at increased risk of HBV infection. ${ }^{11} 12$

Lower socioeconomic status is a recognised risk factor for HBV infection. ${ }^{9}$ This study did not collect data on this, but a reasonable proxy is occupation, and blacks of "low" and "high" status had comparable risk. Occupation, however, reflects only social status, not risk level at birth or during childhood.

Available data from other African countries suggest that viral exposure occurs early in childhood. In Senegal $60 \%$ of children under the age of 10 years had evidence of previous infection. ${ }^{10}$ Studies on HBV marker prevalence during childhood in Zimbabwe have not yet been done, but it is likely that childhood and not adult socioeconomic status is the important facts for exposure. Hospital workers probably acquire HBV markers during their childhood.

Other limitations of this study deserve mention. The hospital group was selected from various parts of the hospital on a volunteer basis. It is difficult to tell what sort of bias might have been introduced by the nonrandom selection of this group. We did not examine some groups of hospital workers, such as laboratory workers, who may be at increased risk. Finally, we did not collect information on occupational status in the donor control group. We were able to examine this risk factor as a possible "explanation" for the observed racial difference in HBV status only within the hospital group.

Our serological data show that previous HBV infection was common among blacks in both the donor and the hospital groups. This risk does not seem to be related to hospital work. For this reason, in the absence of data which show a risk of HBV infection associated with hospital work, routine hepatitis B vaccination of hospital workers is too costly to be justified at this time.

Acknowledgement is hereby given to IBM for their financial support, to Parirenyatwa Hospital for their cooperation, and to the staff of the Blood Transfusion Service, Harare.

\section{References}

1 Dienstag JL, Ryan DM. Occupational exposure to hepatitis B virus in hospital personnel: infection or immunisation? Am J Epidemiol 1982;115:26-39.

2 Levy BS, Harris JC, Smith JL, et al. Hepatitis B in ward and clinical laboratory employees of a general hospital. Am J Epidemiol 1977;106:330-5.

3 Pattison CP, Maynard JE, Berquist DR, et al. Epidemiology of hepatitis B in hospital personnel. Am J Epidemiol 1975;101: 59-64.

4 Jovanovich JF, Saravolatz LD, Arking LM. The risk of hepatitis B among select employee groups in an urban hospital. $J A M A$ 1983;250:1893-4.

5 Panel discussion-Who should be vaccinated against hepatitis B? Symposium on vaccination against hepatitis B. Scand J Infect Dis 1982;Supplement 38:46-61.

6 WHO. WHO Technical Report Series. Hepatitis B vaccines. Geneva: WHO, 1983.

7 Tswana SA. Serologic survey of Hepatitis B surface antigen among the healthy population in Zimbabwe. Cent Afr J Med 1985; 31:45-9.

8 Rothman KJ, Boyce JD. Epidemiologic analysis with a programmable calculator. 79-1649. Washington DC: Department of Health, Education, and Welfare, June 1979.

9 Szumess W. Hepatocellular carcinoma and the hepatitis B virus. Prog Med Virol 1978;24:40-69.

10 Ryder RW, Whittle HC, Wojiecowsky N, et al. Screening for Hepatitis B markers is not justified in West African transfusion centres. Lancet 1984;449-52.

11 Hoffman-Panetta K, Dodd RY. Prevalence of hepatitis B markers in blood center staff: relationship to vaccination policy. Transfusion 1983;23:419-48.

12 Borek DA, Tegtmeier GD, Blosser J, et al. Prevalence of markers of hepatitis B infection in employees of a regional blood center. Transfusion 1983;23:419-49.

Requests for reprints to: Dr J C Emmanuel, The Blood Transfusion Service, PO Box A101, Avondale, Harare, Zimbabwe. 